\title{
Habituation of the blink reflex in the neonatal period and development of auditory processing
}

\author{
Habituação do reflexo cócleo-palpebral no período neonatal e desenvolvimento auditivo
}

\author{
Celina Rech Maggi ${ }^{1}$, Luciane da Costa Pacheco ${ }^{2}$, Tânia Tochetto ${ }^{1}$, Maiara Santos Gonçalves ${ }^{1}$, \\ Fleming Salvador Pedroso ${ }^{3}$
}

\begin{abstract}
Objective: To check the existence of an association between the presence/absence of the blink reflex habituation in the neonatal period and auditory processing development. Methods: The occurrence of blink reflex habituation was studied in 33 neurologically normal neonates, aged between 9 and 25 months, who had their behavioral responses analyzed and classified according to Azevedo (1993). Habituation of the blink reflex was verified using $90-\mathrm{dB}$ sound stimulus. The stage of auditory processing development was evaluated through 41-dB sound stimulus. Statistical data were analyzed with Fischer and $\chi^{2}$ tests. Results: Out of the 33 studied children, 22 presented blink reflex habituation in the first stage of the study. In 7 of them, the auditory processing stage matched their chronological age, while in 15 of them the auditory processing stage was not in accordance with their chronological age. Eleven children failed to present habituation of the blink reflex in the first stage of the study. From this group, eight children presented auditory responses that were appropriate to their chronological age, whereas three had inappropriate responses. A statistically significant association between the presence of blink reflex habituation and auditory processing delay was verified, in addition to an association between the absence of the blink reflex habituation and chronologically suitable responses. Conclusions: The presence of blink reflex habituation in the neonatal period does not seem to be a predictive factor of suitable auditory processing.
\end{abstract}

Keywords: Habituation, psychophysiology; Blink reflex; Infant, newborn; Hearing; Auditory perception; Language

\section{RESUMO}

Objetivo: Verificar a existência de associação entre presença/ ausência de habituação do reflexo cócleo-palpebral no período neonatal bem como o desenvolvimento do processamento auditivo. Métodos: Pesquisou-se a ocorrência de habituação do reflexo cócleopalpebral em 33 neonatos neurologicamente normais, os quais, entre 9 e 25 meses de idade, tiveram suas respostas comportamentais avaliadas e classificadas segundo Azevedo (1993). A habituação do reflexo cócleo-palpebral foi verificada utilizando-se estímulo sonoro de aproximadamente $90 \mathrm{~dB}$. A etapa do desenvolvimento do processamento auditivo foi avaliada com estímulo sonoro aproximado de $41 \mathrm{~dB}$. A análise estatística dos dados foi realizada por meio dos testes Fischer e $\chi^{2}$. Resultados: Das 33 crianças estudadas, 22 evidenciaram habituação do reflexo cócleo-palpebral na primeira etapa do estudo. A etapa do processamento auditivo de 7 delas foi considerada adequada à idade cronológica e de 15 inadequada. Onze crianças não evidenciaram habituação do reflexo cócleo-palpebral na primeira etapa do estudo. Desse grupo, oito crianças manifestaram respostas auditivas adequadas para a idade cronológica e três inadequadas. Verificou-se associação estatisticamente significante entre presença de habituação do reflexo cócleo-palpebral e atraso nas etapas do processamento auditivo, e também entre ausência de habituação do reflexo cócleo-palpebral e respostas adequadas à idade cronológica. Conclusões: A presença de habituação do reflexo cócleo-palpebral no período neonatal parece não ser fator preditivo do adequado desenvolvimento do processamento auditivo.

Descritores: Habituação psicofisiológica; Reflexo cócleo-palpebral; Recém-nascido; Audição; Percepção auditiva: Linguagem

\section{INTRODUCTION}

Habituation is the decrease or the interruption of a response after repeated applications of the same stimulus $^{(1)}$, which is conditioned to the integrity of the central nervous system (CNS) ${ }^{(2)}$.

One of the responses that tend to develop habituation is cochleopalpebral reflex or blink reflex ${ }^{(3)}$. This is one of the most significant reflexes found in neonates submitted to loud sound stimuli ${ }^{(4)}$.

Auditory processing involves reception and interpretation of sound stimuli. Auditory processing

\footnotetext{
Study carried out at Research Laboratory for Pediatric Development at the Center of Speech and Audiology, Universidade Federal de Santa Maria - UFSM - Santa Maria (RS), Brazil.

Universidade Federal de Santa Maria - UFSM - Santa Maria (RS), Brazil.

${ }^{2}$ Graduate Program of Human Communication Disorders of Universidade Federal de Santa Maria - UFSM - Santa Maria (RS), Brazil.

${ }^{3}$ Pediatric Departamento of Universidade Federal de Santa Maria - UFSM - Santa Maria (RS), Brazil.

Received: Sep 07, 2009 - Accepted: Jan 24, 2011

Corresponding author: Celina Rech Maggi - Av. Silva Jardim, 34/703 - Centro - CEP: 95560-000 - Torres (RS), Brazil - Tel.: 51 3664-2119 - e-mail: crechfono@yahoo.com.br
} 
disorder in children could result from neurological disorder, morphological disorganization or maturational delay $^{(5)}$.

During the first year of life, the skill to identify the sound source enables assessing the auditory processing development ${ }^{(6)}$.

Habituation to sound stimulus and auditory processing may be interconnected, which depends on appropriate operation of the CNS.

In 1985, absence of habituation to repeated sound stimuli was associated with future auditory processing disorders in a study carried out with 32 newborns with normal hearing and 32 who failed hearing screening that were reassessed eight years later ${ }^{(7)}$. In 1995, such findings were confirmed by a habituation study on startle reflex in neonates ${ }^{(8)}$.

There was no literature evidence associating blink reflex habituation in the neonatal period and later auditory processing development.

Therefore, based on previously conducted studies, the present investigation aimed to define the correlation between the blink reflex habituation phenomenon observed during the firstmonth oflife and the development of auditory processing skills. Better understanding of this correlation may support early detection and prevention of auditory processing deficits.

\section{OBJECTIVE}

The purpose of the study was to check the existence of an association between blink reflex habituation during the neonatal period and suitability of auditory processing development to chronological age, six months later.

\section{METHODS}

A longitudinal study was carried out and the first stage comprised the occurrence of blink reflex habituation in 85 neonates with no evidence of neurological disorders. To that end, blink reflex was elicited using sound stimuli of about $90 \mathrm{~dB}$ produced by agog bells. Habituation was confirmed when the child had no response to blink reflex for three consecutive times ${ }^{(9)}$. It was noticed that 56 of them developed habituation to sound stimuli, whereas $29 \operatorname{did} \operatorname{not}^{(9)}$.

The present study refers to the second stage, performed six months later.

The parents or guardians of 44 children out of 85 who had participated in the first stage were contacted over the telephone. Two of them refused to take part in the second study; six did not come for the scheduled visit, and three were not assessed because they were crying and they did not come for the new schedule that was made to them.
Thus, a total of 33 children were assessed, and 13 were males. At the time, age ranged from 9 to 25 months.

Data collection was made between May and August 2006 in the Research Laboratory for Pediatric Development (Laboratório de Pesquisa em Desenvolvimento Infantil - LaPeDI), at the Center of Speech and Audiology, Universidade Federal de Santa Maria-UFSM.

Informed consent was obtained from the parents/ guardians of the children.

To determine the auditory processing stage, the distraction technique ${ }^{(10)}$ was used, observing behavioral responses to non-calibrated sounds produced by a plastic rattle with broad frequency spectrum and approximate intensity of $41 \mathrm{~dB}$.

To expand the distraction technique and to observe behavioral responses, the child was positioned seated on the lap of adults, away from their body and held by the waist, in an audiometric booth. An examiner attracted the attention of the child using visual stimulus. At the same time, another examiner (not within the child's visual field) presented the sound stimulus at the positions lateral to the ear pinna, above and below the head. The expected response was localization of the sound source. The responses were considered appropriate in accordance with the chronological age, as shown below:

- Between 6 and 9 months of age: lateral localization (right/left), indirect localization from below;

- Between 9 and 12 months of age: lateral localization, directly localization from below and indirectly from above;

- Between 12 and 15 months of age: lateral localization, direct localization from below and indirect from above ${ }^{(11)}$.

The responses that were not within the parameters set as reference were considered to be inappropriate.

Moreover, the variables that could generate false results, such as visual, tactile and/or olfactory cues were controlled.

The association between the variables was checked using the chi-squared test $\left(\chi^{2}\right)$. When one of the expected frequencies was below 5\%, the Fischer exact test was used for tables $2 \times 2$.

To test the association between gender and auditory processing stage and the frequency of habituation and auditory processing stage, we used the $\chi^{2}$ test.

Fischer exact test was used to test the association between gender and frequency of habituation and also gender and auditory processing. The acceptable significance level was $5 \%$.

This study is part of the activities of the research project named "Preventive medicine in rooming-in babies at HUSM based on early detection of risk factors 
for children development", approved by the Ethics Committee of UFSM, under number 095/04.

\section{RESULTS}

Figure 1 shows the occurrence of blink reflex habituation checked in neonatal period according to child gender (first step of the study). There were no statistically significant differences between boys and girls concerning presence or absence of blink reflex habituation ${ }^{(9)}$.

In the second stage of the study, upon assessing auditory processing, there were no statistically significant differences between the genders (Figure 2 ). Thus, the results obtained for both genders were analyzed together. Figure 3 shows the results of the auditory processing assessment without gender differentiation.

Considering the children who showed habituation of blink reflex in the first step of the study, there was predominance of inappropriate results according to age in the assessment of auditory processing. Among those that did not show blink reflex habituation in the first stage, there was predominance of appropriate performance in auditory processing (Figure 4).

\section{DISCUSSION}

The occurrence of blink reflex habituation during the neonatal period was similar in both genders (Figure 1), even though habituation to repeated auditory stimuli occurs more rapidly in girls ${ }^{(12)}$.

The performance of girls and boys in the assessment of auditory processing stage did not show statistically significant differences (Figure 2), as reported by other authors $^{(6,13)}$.

The absence of association between presence of blink reflex habituation and appropriate behavioral responses for chronological age was observed, as expected. Similarly, children who have not manifested blink reflex habituation in the neonatal period predominantly had auditory responses appropriate for their age (Figure 4). Such results are not in accordance with the literature studied, which states that absence in habituation to repeated sound stimuli may predict future abnormalities of auditory processing ${ }^{(7,8)}$.

The correlation between repeated auditory stimuli habituation and auditory processing may be understood based on many studies that correlate both functions to CNS integrity, since the first years of life ${ }^{(14-20)}$.

Habituation is a basic learning skill linked with CNS integrity ${ }^{(16)}$, a phenomenon that belongs to stimuli processing ${ }^{(17)}$. Such phenomenon would depend on

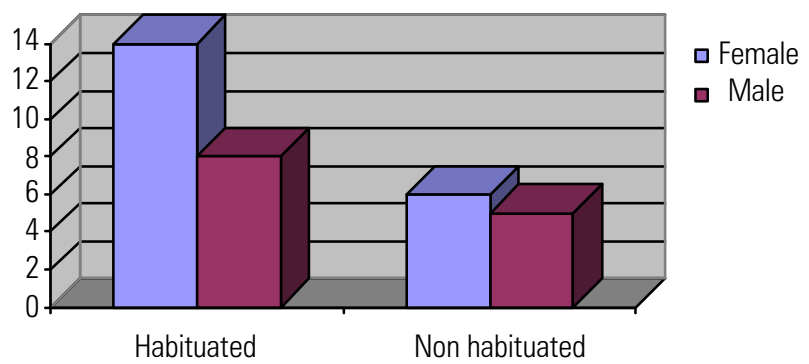

Figure 1. Occurrence of habituation of the blink reflex in the neonatal period, according to gender. $p=1.00$ - Fisher exact test

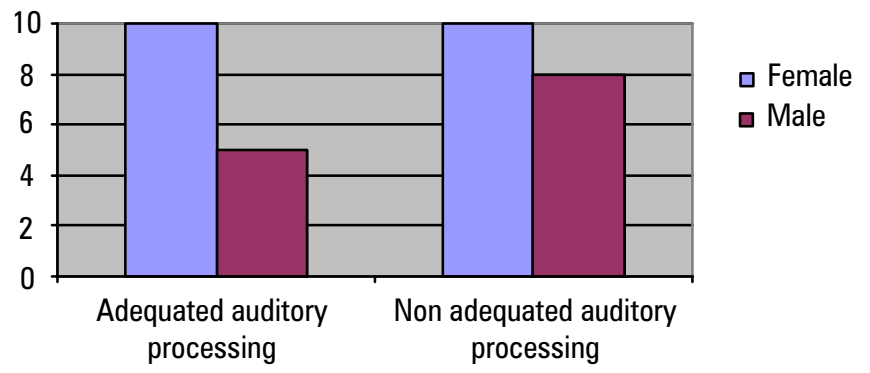

Figure 2. Performance in assessment of auditory processing according to gender; $p=0.515$ - Fisher's exact test

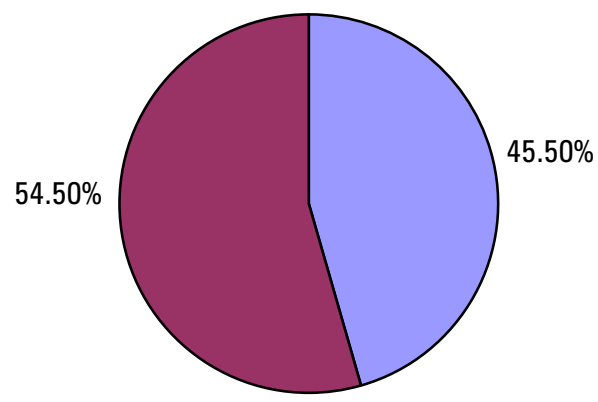

口 Non adequated auditory processing

$\checkmark$ Adequated auditory processing

Figure 3. Results of assessment of auditory processing.

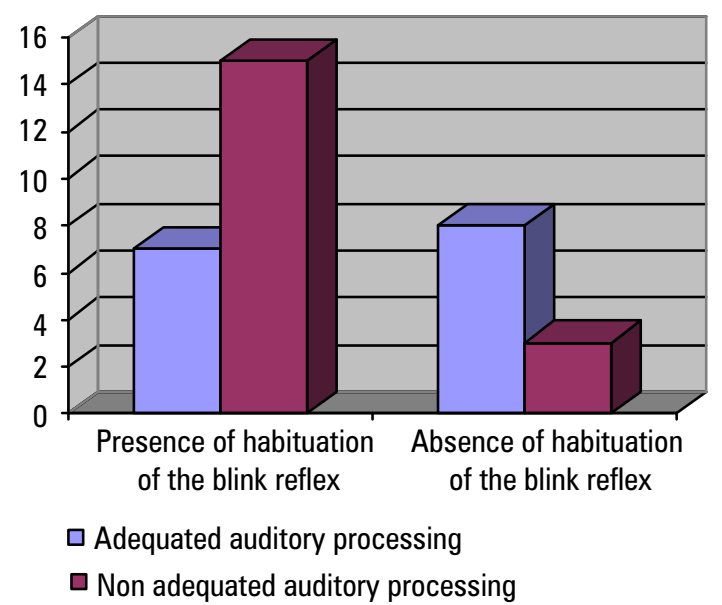

Figure 4. Occurrence of habituation of the blink reflex and performance in assessment of auditory processing. $p=0.026^{*}$ - Chi-squared test 
active cortical inhibition of response ${ }^{(14)}$ and it would be a common neuron reaction, involving physiology of the neurons, as well as the interneural, intercortical and probably cortical-subcortical connections ${ }^{(19)}$. The habituation phenomenon could identify possible deficits in CNS operation ${ }^{(18)}$. Conditions that affect this system would act similarly over habituation ${ }^{(15)}$.

Auditory processing is also related with central auditory functions $\mathbf{s}^{(7,21,22)}$.

Auditory processing disorder in children can result from neurological disorder, morphological disorganization, maturational delay ${ }^{(5)}$, neuromorphological dysfunction, delay in central nervous system maturation, and neurological and otological disorders, diseases or lesions ${ }^{(23)}$.

Based on literature data, children who did not show blink reflex habituation in the first step of the study were expected to present inappropriate auditory responses to their chronological age, which did not prove to be true. A possible maturation of the central auditory system between the first and the second tests was considered.

Abnormalities of auditory assessment found in high-risk children may disappear in the second half of the first year. This fact could be attributed to the CNS maturation process. When this normalization does not take place, auditory processing abnormalities may have resulted from neurological impairment ${ }^{(7)}$. According to some authors, the auditory system is immature at birth and goes through many changes during the postnatal period $^{(24)}$. Others argue that the baby auditory system, being plastic, could be modified by acoustic stimuli ${ }^{(25)}$.

Sound localization skills depend on innate biological capability and environmental experiencing(26). Poor acoustic stimulation could be responsible for the high percentage of inappropriate responses to chronological age $(54 \%)$.

It should also be taken into account that there are slight differences in auditory development stages according to different authors ${ }^{(11,21,25)}$. The sample in the present study could have differed concerning the environmental and regional characteristics of the sample taken as a parameter for this study ${ }^{(11)}$.

Habituation should be analyzed in the neonatal hearing assessment to detect early signs of auditory processing deficit ${ }^{(7,8)}$. However, results present in this study make us believe that the occurrence of blink reflex habituation in the neonatal period does not seem to be a predictive factor for appropriate auditory processing development.

The influence of auditory processing abnormalities over the development of language skills has been highlighted in many studies ${ }^{(22,27-30)}$. Therefore, further investigations about early manifestations of auditory processing disorders are required to minimize and prevent occasional linguistic difficulties.

Other studies may clarify possible causes of abnormalities to auditory processing, considering differences in environmental stimulation and neurodevelopment conditions.

\section{CONCLUSION}

Based on the results found in this study, the presence of blink reflex habituation in the neonatal period does not seem to be a predictive factor of the appropriate development of auditory processing between 9 and 25 months of age.

\section{REFERENCES}

1. Morokuma S, Fukushima K, Kawai N, Tomonaga M, Satoh S, Nakano H. Fetal habituation correlates with functional brain development. Behav Brain Res. 2004;153(2): 459-63.

2. James D. Fetal behaviour. Current Obst Gynaecol. 1997;7:30-5.

3. Hodgson WR. Avaliação de bebês e crianças pequenas. In: Katz J. Tratado de Audiologia Clínica. São Paulo: Manole; 1999. p. 461-72.

4. Azevedo MF, Vieira RM, Vilanova LCP. Desenvolvimento auditivo de crianças normais e de alto risco. São Paulo: Plexus; 1995.

5. Musiek FE, Baran JA, Pinheiro ML. Central auditory processing disorders in children and adults with learning disabilities. In: Musiek FE, Baran JA, Pinheiro ML. Neuroaudiology case studies. San Diego: Singular; 1993.

6. Costa AS, Azevedo MF, Fukuda Y. Localização sonora em crianças: grau de movimentação da cabeça e latência de resposta. Pró-Fono. 2003;15(2): 160-80.

7. Mencher GT. Hearing screening programs and identifications of central auditory disorders. Hum Commun Can. 1985;9(4):45-9.

8. Zanchetta S, Suzuki MR, Azevedo MF, Vilanova LC, Goulart AL Identificação de alterações auditivas centrais em crianças de alto risco. Acta Awho. 1995;25(2):65-8.

9. Maggi CR, Tochetto T, Pacheco LC, Gonçalves MS, Pedroso FS. Habituação do reflexo cócleo-palpebral em neonatos. Temas Desenvolv. 2006;15 (85-86):35-7.

10. Ewing I, Ewing AWG. The ascertainment of deafness in infancy and early childhood. J Laryngol Otol. 1944;59:309-33.

11. Azevedo MF. Avaliação subjetiva da audição no primeiro ano de vida. Temas sobre Desenvolvimento. 1991;3:11-4.

12. Mencher GT, Mencher LS, Rohland SL. Maturation of behavioral response. Ear Hear. 1985;6(1):10-4.

13. Soares CD. Habilidades de sequencialização sonora não verbal e verbal e de localização sonora em pré-escolares. Pró-Fono. 1998;10(2): 34-40.

14. Fitzgerald HE. Desenvolvimento dos sistemas de percepção. In: Fitzgerald HE. Psicologia do desenvolvimento: o bebê e a criança pequena. Rio de Janeiro: Campus; 1986.

15. Gandhavadi B, Melvin JL. Electrical blink reflex habituation in mentally retarded adults. J Ment Defic Res. 1985;29(Pt 1):49-54.

16. Kisilevsky BS, Muir DW. Neonatal movement response decrement and recovery to sounds as a function of stimulus intensity. Can J Exp Psychol. 1993;47(4):639-56. 
17. Broersen LM, Uylings HB. Visual attention task performance in Wistar and Listar hooded rats: response inhibition deficits after medial prefrontal lesions. Neuroscience. 1999;94(1):47-57.

18. van Heteren CF, Boekkooi APF, Jongsma HW, Nijhuisc JG. Fetal habituation to vibroacoustic stimulation in relation to fetal states and fetal heart rate parameters. Early Hum Dev. 2001;61(2):135-45.

19. Backes D apud Pfleiderer B, Ostermann J, Michael N, Heindel W. Visualization of auditory habituation by fMRI. Neuroimage. 2002;17(4):1705-10.

20. Bellieni CV, Severi F, Bocchi C, Caparelli N, Bagnoli F, Buonocore G, et al. Blink-startle reflex habituation in 30-34-week low-risk fetuses. J Perinat Med. 2005;33(1):33-7.

21. Murphy KP. Development of hearing in babies. Child Fam. 1962;1(1):16-27.

22. Jaffe $M$, Tirosh $E$, Orian D, Shenhave R. Immature sound localisation and abnormal development. Arch Dis Child. 1986;61(9):858-61.

23. Alvarez AMMA, Ballen S, Misorelli MIL, Sanchez ML Processamento auditivo: proposta de avaliação e diagnóstico diferencial. In: Munhoz MSL, Silva MLG, Ganança MM, Caovilla HH. Audiologia clínica. São Paulo: Atheneu; 2000. p. 103-20.
24. Sharma A, Dorman MF, Kral A. The influence of a sensitive period on central auditory development in children with unilateral and bilateral cochlear implants. Hear Res. 2005;203(1-2):134-43.

25. Northern JL, Downs MP. Desenvolvimento do comportamento auditivo. In: Northern JL, Downs MP. Audição em crianças. São Paulo: Manole; 1989. p. 101-41.

26. Pereira LD, Cavadas M. Processamento auditivo central. In: Frota $S$. Fundamentos em fonoaudiologia: audiologia. Rio de Janeiro: Guanabara Koogan; 2003.

27. Downs MP, Roeser RJ. Auditory disorders in school children. New York: Thieme Medical Publishers; 1988.

28. Flores MAG, Miaciro CV. Estudio de la vía auditiva central por medio de las respuestas evocadas auditivas del tronco encefálico (ABR) en niños con retraso en el lenguaje. An Fac Med. 2003;64(1):27-33.

29. Bishop DVM, Mcarthur GM. Immature cortical responses to auditory stimuli in specific language impairment: evidence from ERPs to rapid tone sequences. Dev Sci. 2004;7(4): 11-8.

30. Kaminski JM, Tochetto T, Mota HB. Maturação da função auditiva e desenvolvimento de linguagem. Rev Soc Bras Fonoaudiol. 2006;11(1):17-21. 